\title{
Efeitos colaterais da desmedicalização
}

Publicado em Interface - Comunicação, Saúde, Educação, v.16, n.40, o texto de Gaudenzi e Ortega (2012) merece atenção por contestar uma tendência predominante, cujos efeitos são bastante amplos e graves: $a$ intensificação da medicalização da vida humana. Apontando para os limites científicos e pautando certos parâmetros ético-políticos, os autores argumentam a favor da desmedicalização. Basicamente a partir de Michel Foucault e Ivan Illich, organizam sua crítica ideológica e sociopolítica da medicalização, defendendo a ideia de desmedicalização como resistência. Opõem, à vigente ideologia medicalizante, uma ideologia desmedicalizante, assumindo uma perspectiva que comentamos e interrogamos, exprimindo nosso interesse e expectativa pelo futuro desenvolvimento da reflexão que é apresentada, no texto, como "[...] uma introdução ao tema da medicalização e dos movimentos desmedicalizantes" (p.31).

Em tempos de revolução biotecnológica, caracterizada pela ampliação das biotécnicas diagnósticas, terapêuticas, manipuladoras ou "aperfeiçoadoras", recusar o diagnóstico e intervenção médicos pode soar irracional, dogmático ou um contrassenso. Entretanto, tais pechas são claramente inapropriadas à interrogação do poder médico proposta pelos autores.

Semelhantemente, é inadequado chamá-los de bioconservadores. Esposando uma (problemática) fronteira entre terapia e aperfeiçoamento, o bioconservadorismo, grosso modo, aduz fundamentos religiosos e/ou metafísicos, sustentando que devemos nos limitar ao tratamento das anormalidades (doenças, deficiências e disfunções biológicas). Ultrapassar essa (suposta) fronteira comprometeria coisas como a dignidade humana, a liberdade, a autonomia e a moralidade. Somente a intervenção terapêutica seria moralmente justificável, o que, por conseguinte, confere à medicina uma espécie de "salvo-conduto" parcial, mas bastante amplo e constantemente ampliável. Isto porque, por um lado, tudo que é doença pode ou deve sofrer uma intervenção medicalizadora. Por outro, como o processo de patologização dos fenômenos biológicos só progride, porquanto cada vez mais doenças são criadas - como Márcia Angell, renomada médica norte-americana, denunciou num recente artigo ${ }^{1}$, especificamente sobre doenças mentais -, o campo da medicalização só amplia-se. Diferentemente da bioconservadora, a perspectiva defendida pelos autores é a de que até mesmo a "obrigação terapêutica" é questionável. Para eles, o comprometimento da autonomia e diversidade exemplifica problemas afetos à medicalização.

Na sua argumentação, citam exemplos diversificados de luta pela desmedicalização - bastante atuais por sinal -, como o movimento pelo parto domiciliar. Recentemente, o Conselho Regional de Medicina do Rio de Janeiro (CREMERJ) vetou a participação de médicos em tais procedimentos ${ }^{2}$. Segundo matéria publicada em seu Jornal ${ }^{3}$, o procedimento é um contrassenso, pois nega os avanços da medicina. Nota-se que um fenômeno biológico considerado normal é tido como obrigatoriamente dependente de meios artificiais e heterônomos, que são custosos, para alguns, e rentáveis, para outros.

\footnotetext{
${ }^{1}$ Disponível em: < http:// revistapiaui.estadao.com.br/ edicao-59/questoes-medicofarmacologicas/a-epidemia-dedoenca-mental >. Acesso em: 28 jul. 2012.

${ }^{2}$ Resoluções CREMERJ n. 265/12 e n. 266/12. Disponíveis em: $<$ http://www.cremerj.org.br/ skel.php?page $=$ legislacao/ resultados.php >. Acesso em: 28 jul. 2012

${ }^{3}$ Disponível em: <http:// www.cremerj.org.br/jornais/ mostraMateria. php?idJornal $=53 \&$ id Materia $=857>$. Acesso em: 28 jul. 2012
} 
Inobstante, seu foco está nas doenças e deficiências, tidas, geralmente, como anormalidades, o que as torna alvo obrigatório de medicalização. É clara a pertinência da proposta dos autores de abertura à discussão do diagnóstico e da terapêutica médicos, questionando as bases científicas, culturais e ideológicas da ciência, bem como seus efeitos. Não é necessário detalhá-los aqui. Apenas interrogamos a abordagem, excogitando alguns efeitos colaterais, convidando-os a considerá-los no desenvolvimento da sua reflexão.

Algumas críticas à medicalização são hiperbólicas, sustentando que medicalizar é tornar os indivíduos dependentes. Mas será que todo o processo de medicalização - termo com sentido crítico ou negativo - gera apenas efeitos maléficos? As tecnologias médicas ameaçam a "liberdade" e a "autonomia" absolutamente? O radicalismo de Illich é factualmente justificável, ou, à semelhança da higiomania ou da moralidade da saúde, é uma ideologia porosa, prenhe de convicções inflacionadas e contestáveis? Por exemplo, será que a contraideologia desmedicalizadora é suficiente para resgatar a "autonomia" humana? Além da vagueza do conceito, tal perspectiva parece-nos exacerbada, porquanto resumiria a superação da heteronomia a apenas uma ação política.

Sobre as noções de doença e deficiência, embora sejam produtos históricos, alusivos a juízos de valor, seria implausível afirmar que se referem, outrossim, a fatos biológicos? Resumir deficiência, por exemplo, a um ardil capitalista parece-nos impróprio. Consoante Glover (2006), deficiência não é bem compreendida como mera diversidade ou desvantagem socialmente construída, mas como uma limitação funcional, a qual, conforme Carmichael (2003), causa sofrimento ao indivíduo e seus familiares.

É questionável compreender, por exemplo, uma deficiência mental grave, incapacitante, como um produto meramente social e ideológico. À medida que compromete importantes funcionamentos, os quais não são meras conveniências capitalistas, mas inerentes à biologia humana, ela comprime o horizonte de realizações, podendo tornar um indivíduo absolutamente dependente e heterônomo. No nosso entendimento, a medicalização dirigida à prevenção ou tratamento pode até garantir algumas condições fundamentais, embora não suficientes, do exercício de algo como a "autonomia".

Outro ponto concerne à tensa relação entre liberdade $e$ responsabilidade individuais, considerando os efeitos coletivos das opções particulares. Para tanto, usamos o exemplo da vacinação. Supondo a eficácia deste procedimento medicalizador, um indivíduo vacinado torna-se mais resistente ou imune a dada contaminação, o que beneficia a ele e aos outros. Se esse indivíduo recusa-se a ser vacinado, em tese, ele estaria mais suscetível a adoecer, bem como, no caso de doenças transmissíveis entre humanos, a ser um agente contaminador, o que pode prejudicar outros indivíduos e aumentar os gastos públicos. Em nome da liberdade de se desmedicalizar, perguntamos, tal atitude deve ser promovida, ainda que seus efeitos sejam coletivamente indesejáveis ou prejudiciais? Ao invés, não é razoável que um cidadão seja chamado à responsabilidade por uma comunidade sciopolíticobiológica em que se insere, sendo impelido à vacinação?

Por fim, deixamos três questões: (1) Conforme a crítica à medicalização, a desmedicalização deve ser limitada? (2) Se a desmedicalização tornar-se regra, não haverá uma simples inversão nas relações de biopoder, colocando novas forças em destaque e uma nova ideologia em operação, à qual, dir-se-á posteriormente, devese resistir? (3) A defesa radical da desmedicalização não pode justificar uma problemática minimização estatal no tocante à saúde, agravando sua já precária assistência?

\section{Murilo Mariano Vilaça ${ }^{1}$ Alexandre Palma ${ }^{2}$}

${ }^{1}$ Programa de Pós-Graduação em Filosofia, Universidade Federal do Rio de Janeiro (UFRJ). Largo de São Francisco de Paula, ${ }^{\circ}$

1. Centro, Rio de Janeiro, RJ, Brasil. 20.051 070.contatoacademico@hotmail.com

2 Programa de Pós-graduação s tricto sensu em Educação Física, Escola de Educação Física e Desportos, UFRJ.

\section{Referências}

CARMICHAEL, B. The human genome project: threat or promise? J. Intellec. Disabil. Res., v.47, n.7, p.505-8, 2003. GLOVER, J. Choosing children: genes, disability, and design. Oxford: Clarendon Press, 2006. 